\title{
HET WINSTBEGRIP, FISCAAL EN ECONOMISCH
}

\author{
door D. A. M. Meeles
}

Van een fiscaal winstbegrip met eigen inhoud kan hier te lande eerst sinds omstreeks 1940 worden gesproken. Van die tijd dateren namelijk de Besluiten op de Inkomstenbelasting, de Winstbelasting en de Vennootschapsbelasting.

De belastingplichtige rechtspersonen waren voordien slechts onderworpen aan een uitdelingsbelasting, de Dividend- en Tantièmebelasting, waarbij alleen in uitzonderingsgevallen de vraag aan de orde kwam of wat was uitgedeeld ook werkelijk winst was. De heffing van inkomstenbelasting van de particuliere ondernemers sloot zich destijds aan bij de op redelijke wijze gevoerde commerciële boekhouding. Het toenmaals geldende systeem van de wet, waarbij alleen van de bij het begin van het belastingjaar nog door de belastingplichtige gedreven ondernemingen de winst - bij wijze van fictie bepaald op basis van de winst behaald in het voorafgaande jaar - belastbaar was, bracht de belastingrechter er toe winstbepalingssystemen, welke tot ,winstverschuiving" konden leiden minder snel te accepteren. De ondernemer had het $\mathrm{nl}$. in de hand door vervreemding of liquidatie van zijn onderneming vóór de aanvang van het volgende belastingjaar, alle „verschoven" winsten definitief buiten de belastingheffing te brengen. Om deze reden werd een beroep op toepassing van bedrijfseconomische beginselen bij de fiscale winstbepaling meermalen door de belastingrechter verworpen. Zo werd in een arrest van 30 juni $1921^{1}$ ) beslist dat afschrijving op basis van (hogere) vervangingswaarde niet was toegestaan. Voorts werd aangenomen dat ook de toepassing van het ijzeren-voorraadstelsel bij de Hoge Raad geen genade kon vinden. ${ }^{2}$ )

Sinds 1940 is de belastingheffing naar de winst voor particulieren zowel als voor rechtspersonen gebaseerd op een winstbegrip met tweeledig karakter. Uitgangspunt is, wat in fiscale kringen wordt aangeduid als de totale winst, dat is de winst die tussen begin en einde van de onderneming, c.q. van de belastingplicht van de ondernemer, is behaald. Dit onderdeel van het fiscale winstbegrip is door de bedrijfseconomie stiefmoederlijk bedeeld. De bedrijfseconoom interesseert zich uitsluitend voor problemen, welke zich in de continuïteit van de onderneming voordoen; de fiscus verbindt met betrekking tot de fiscale winstbepaling echter ook gevolgen aan de beëindiging van de onderneming of het eindigen van de belastingplicht van de ondernemer. De totale winst wordt daarbij zonder uitzondering opgevat in nominalistische zin. Kernachtig werd dit uitgedrukt in de Leidraad bij de Wet Belastingherziening 1950: „Over de gehele duur van de onderneming genomen is winst al hetgeen, in guldens gerekend, meer wordt genoten dan oorspronkelijk aan kapitaal is ingebracht, ongeacht de waardeveranderingen die de munteenheid kan hebben ondergaan". Noch tijdens de levensduur van de onderneming, noch bij beëindiging daarvan worden dus correcties toegepast ter zake van waardefluctuaties in de geldeenheid. Ter verdediging van dit zgn. gulden-is-

1) B 2849

2) Arrest van 20 juni 1923, B 3259. Terecht heeft Mr A. J. van Soest in zijn inleiding op de Belastingconsulentendag 1958 betwijfeld of deze conclusie inderdaad uit het arrest mocht worden getrokken. 
guldenstelsel is wel aangevoerd dat ook de bedrijfseconomie niet leert, dat de totale winst van een onderneming iets anders is dan het bedrag aan guldens hetwelk bij beëindiging van de bedrijfsuitoefening meer blijkt te zijn ontvangen dan destijds werd geïnvesteerd. Van bedrijfseconomische zijde is daarop terecht gereageerd met de opmerking dat de belastingheffer weliswaar autonoom is in de vaststelling van het object van heffing, maar dat men een heffing over een waarde-aanwas, veroorzaakt door de waardedaling van de geldeenheid, dan niet als winstbelasting (doch als vermogensheffing) moet aanduiden ${ }^{3}$ ). Het ligt voor de hand, dat ook van de zijde van de fiscale deskundigen het fiscale totaalwinstbegrip bestrijding ontmoette. Een door de Vereniging voor Belastingwetenschap ingestelde commissie kwam in 1960 tot de conclusie dat het fiscale winstbegrip zal dienen te worden gezuiverd van de invloeden van geldwaardeveranderingen ${ }^{4}$ ). Noch de zgn. stakingsfaciliteiten (franchise, bijzonder tarief en stamrechtvrijstelling bij bedrijfsbeëindiging door natuurlijke personen), noch de zgn. doorschuifmogelijkheden, kunnen bij een snel voortschrijdende geldontwaarding als waarmede wij in de afgelopen jaren zijn geconfronteerd, de bezwaren tegen het gulden-is-guldenstelsel voldoende ondervangen.

De totale winst speelt als zodanig bij de jaarlijkse aanslagregeling geen rol. Maatstaf van heffing is nl. de jaarwinst, dat is dat deel van de totale winst dat aan het belastingjaar kan worden toegerekend.

Men zou uit het vorenstaande kunnen afleiden dat, nu de wetgever de vóór 1940 bestaande mogelijkheid tot het ontgaan van de belasting over de totale winst had ondervangen, geen beletselen meer zouden behoeven bestaan om de jaarwinstbepaling, bij uitstek een bedrijfseconomisch onderwerp, te baseren op wat de bedrijfseconomie daaromtrent leert. Zo dit er toe zou leiden dat enig deel van de totaalwinst naar toekomstige jaren zou worden ,verschoven" dan zou dit in het nieuwe stelsel slechts uitstel van heffing en geen afstel tengevolge hebben. De wetgever heeft evenwel geopteerd voor een fiscaal winstbegrip met eigen inhoud.

De met ingang van 1941 geldende voorschriften, opgenomen in het Besluit op de Inkomstenbelasting, waren gebaseerd op de in Duitsland geldende regelen. In de fiscale winstbepalende balans - de fiscale jaarwinst werd door vermogensvergelijking bepaald - moesten de aktiva ten minste worden gewaardeerd op historische aanschaffingsprijs (behoudens aantoonbaar lagere bedrijfswaarde), terwijl de afschrijving op de duurzame produktiemiddelen werd gebonden aan de historische aanschaffingsprijs. De mogelijkheid om de juist op deze punten ontwikkelde moderne bedrijfseconomische inzichten in toepassing te brengen werd dus volledig afgesneden.

Slechts gedeeltelijk kwam hieraan een einde doordat in 1950 de minimumwaarderingsregel voor de vlottende bedrijfsmiddelen $\mathrm{kwam}$ te vervallen. Sindsdien is het o.m. toegestaan bij de fiscale winstbepaling op de goederenbeweging gebruik

3) Aldus Prof. H. J. van der Schroeff in Geschrift nr 97 van de Vereniging voor Belastingwetenschap blz. 22.

4) Rapport van de "Commissie ter bestudering van de mogelijkheden van toepassing van substantialistische winstopvattingen op het fiscale terrein", Geschrift nr 103 van de Vereniging voor Belastingwetenschap. 
te maken van het ijzeren-voorraadstelsel met mancoreserve. Overigens heeft de Hoge Raad uitgemaakt dat toepassing bij de fiscale winstbepaling van hetgeen de bedrijfseconomie ons daaromtrent leert niet mogelijk is voorzover daardoor in strijd wordt gehandeld met enig voorschrift der belastingwetgeving dan wel indien daardoor aan de algemene opzet of een beginsel van de belastingwet om welker toepassing het gaat te kort zou worden gedaan ${ }^{5}$ ). Toepassing van de vervangingswaarde-gedachte ten aanzien van de duurzame produktiemiddelen is dus voor de fiscale winstbepaling uitgesloten, omdat de wet dit niet toelaat.

Het is ondoenlijk in het kader van een tijdschriftartikel de ontwikkeling van het fiscale jaarwinstbegrip tegen de achtergrond van de daaromtrent gehuldigde bedrijfseconomische opvattingen ook maar enigszins uitputtend te behandelen. De belangstellende lezer kan niet beter doen dan op dit punt kennis te nemen van het proefschrift van Dr D. Brüll, aan welk proefschrift W. E. Kremer in het maartnummer van deze jaargang een artikel wijdde ${ }^{6}$ ). Men zal zich daarbij moeten realiseren, dat ook Brüll in zijn toch zeer omvangrijke proefschrift niet aan een uitputtende behandeling van het jaarwinstbegrip kon toekomen: „Slechts de grensgebieden van de jaarwinstbepaling, de principiële strijdpunten zullen belicht worden en van deze slechts de symptomatische aspecten"7). Men late zich voorts niet weerhouden door het feit, dat Brüll zijn proefschrift in het voorjaar 1964 moest afsluiten en dus aan de met ingang van 1965 ingetreden wetswijzigingen slechts beperkte aandacht kon schenken. Opzet en gehalte van het werk maken dat het voor een diepgaand inzicht in het fiscale winstbegrip blijvende waarde behoudt.

In het inleidende artikel van Wisselink wordt een aspect van de fiscale winstbepaling aangeroerd waaraan Brüll in zijn proefschrift vrijwel niet is toegekomen. Ik doel hier op het adagium dat bij de keuze van een fiscaal systeem het recht moet erkend worden, dat het financieringsmoment van de te betalen belastingen daarbij een rol mag spelen. Mede in verband met de voorafgaande artikelen wil ik aan dit aspect in het navolgende nog enige aandacht schenken.

Beziet men de belastingheffing naar het inkomen dan wordt in het algemeen het voor de belastbaarheid beslissende moment daar gelegd, waar het inkomen in liquide vorm ter beschikking komt. Het uit het beginsel van de minste pijn ${ }^{8}$ ) voortvloeiende pay-as-you-go-principe probeert de belastingheffing zoveel mogelijk bij het liquide beschikbaar komen van het inkomen te doen aansluiten. De instituten van loonbelasting, dividendbelasting en voorlopige aanslagen vormen daarvan een uitvloeisel. Het beginsel wordt echter bij de belastingheffing over de bedrijfswinst geheel losgelaten. Niet alleen wordt de over enig belastingjaar berekende winst in de belastingheffing over dat jaar betrokken en wordt daarbij aan de doorgaans aanwezige noodzaak van interne financiering geheel voorbijgegaan, doch bovendien wordt hier te lande zonder enige restrictie het over het nog lopende jaar te verwachten resultaat betrokken in de voorlopige aanslagregeling. Daarbij wordt er van uitgegaan, dat de belasting over het jaar ook in het jaar zelf volledig moet

5) Arrest van 8 mci 1957, B.N.B. 1957/208.

b) Beschouwingen naar aanleiding van "Objectieve en subjectieve aspecten van het fiscale winstbegrip" van Dr D. Brüll.

7) T.a.p. blz. 128 .

8) Vgl. het aangehaalde artikel van Kremer, m.a.b. maart 1967, blz. 103. 
zijn betaald. Een uitzondering geldt daarbij voor de rechtspersonen, die in het jaar zelf in het algemeen niet meer dan $75 \%$ van de vermoedelijk over het jaar verschuldigde belasting op voorlopige aanslag moeten voldoen.

Kennelijk heeft de wetgever niet onderkend dat het karakter van de winstbepaling niet is de constatering van wat over enig jaar in dat jaar ter vertering beschikbaar is gekomen, zoals dat wèl het geval is met de in enig jaar genoten salarissen, dividenden en andere inkomsten. Winstbepaling is ex post, gericht op de vaststelling van wat, de gang van zaken in de afgelopen periode in aanmerking genomen, na afloop van deze periode als gerealiseerde winst, dus in principe vatbaar voor vertering nadien kan worden aangemerkt.

De algemeen gebruikelijke winstbepalingstechnieken zijn op dit uitgangspunt gebaseerd. Wil men de winst leren kennen die al tijdens de loop van het boekjaar ter vertering beschikbaar komt, zoals in kleine bedrijven en vrije beroepen wel voorkomt, dan pleegde daarvoor veelvuldig het zgn. kasstelsel ${ }^{9}$ ) te worden gebezigd.

Het is vanzelfsprekend, dat bij de winstbestemming, die op de winstbepaling logisch aansluit, aan de aanspraken van de fiscus volledig recht behoort te worden gedaan. Belastingheffing is immers bij uitstek een winstbestemmingsfaktor. Op het moment, waarop de ondernemer zelf over de winst beschikt, dient ook de fiscus aan zijn trek te komen. Men kan zich hierbij reeds afvragen of het, voor het geval de ondernemer uit een oogpunt van bedrijfsbeleid tot reservevorming, dus tot winstinhouding zou moeten besluiten, redelijk is dat aan de aanspraken van de fiscus contant moet worden voldaan. Zo men deze vraag ontkennend zou beantwoorden komt men voor het probleem te staan dat het wel zeer bezwaarlijk lijkt de fiscus in een soort crediteurenverhouding aan de onderneming te binden. Dit is evenwel ook niet nodig. Indien, zoals Wisselink voorstaat, reeds bij de fiscale winstbepaling met de eisen van de fiscus op contante betaling rekening zou mogen worden gehouden - hetgeen dus op stille-reservevorming neerkomt dan blijven door de bovenomschreven wetsbepalingen de aanspraken van de fiscus volledig, zij het latent, behouden.

Het is echter niet alleen dit aspect van de belastingheffing, waarop Wisselink doelt. Naar het voorkomt slaat zijn pleidooi voor toelating van het liquiditeitsprincipe bij de fiscale winstbepaling mede op de reeds gereleveerde heffingstechniek, waarbij de fiscus zich, in tegenstelling tot zijn medeparticipanten, niet alleen op volledige contante uitbetaling van zijn aandeel doet voorstaan, doch bovendien zijn aanspraken reeds een half tot een vol jaar te vroeg geldend maakt. Niet ten onrechte circuleert onder de particuliere ondernemers het wrange grapje dat de heffingstechniek van de fiscus medebrengt dat, zou men het ongeluk hebben een bijzonder goed jaar te maken, dit tezelfdertijd de noodzaak zou scheppen surséance van betaling aan te vragen!

$\left.{ }^{9}\right)$ Zie het artikel van schrijver dezes in Belastingbeschouwingen van mei 1967 „Fiscale winstbepaling in de vrije beroepen".

m a b blz. 349 
Het is duidelijk, dat het liquiditeitsprincipe in de fiscale jaarwinstbepaling minder ver behoeft te worden doorgevoerd indien de fiscus voor de winst uit onderneming van het opleggen van voorlopige aanslagen zou afzien. Het principe blijft echter ook dan gelding behouden voorzover de redelijkheid medebrengt, dat de fiscus de ondernemer bij de noodzaak tot interne financiering niet volledig in de steek laat. Uiteraard is dit niet alleen een Nederlands probleem. Men vergelijke in dit verband de opmerking in het artikel van Delattre, dat op dit punt ook de (Franse) Staat als winstgerechtigde zijn medegerechtigden lelijk in de kou laat staan.

$\mathrm{Nu}$ is het hier te lande bepaald niet zo, dat wetgever en belastingrechter de belastingplichtigen op het punt van het liquiditeitsbeginsel en de noodzaak tot interne financiering iedere steun hebben onthouden. Wat de wetgever betreft denke men aan de bepalingen omtrent investeringsaftrek en vervroegde afschrijving, vervangingsreserve, geruisloze doorschuiving van ondernemingen e.d. Ook de belastingrechter heeft in zekere mate het liquiditeitsbeginsel aanvaard o.m. in de arresten betreffende het ijzeren-voorraadstelsel, de eliminering van de constante kosten bij de balanswaardering, de waardering van huurkoopdebiteuren, het kasstelsel, toepassing van de zgn. ruilgedachte, de boekwaarde-afschrijving e.d.

In de in dit nummer opgenomen artikelen omtrent het winstbegrip buiten onze grenzen onderkent men evenzeer het zoeken naar integratie van het liquiditeitsprincipe in het fiscale winstbegrip. Enerzijds kan worden gewezen op maatregelen, welke ook hier te lande bekend zijn als vervroegde afschrijving (bv. - beperkt - in Duitsland en Engeland), investeringsaftrek (eveneens in Duitsland en Engeland), vervangingsreserve (Engeland, Frankrijk en Duitsland), boekwaardeafschrijving (Duitsland en Frankrijk), huurkoopwaardering (U.S.A.); anderzijds komen wij mogelijkheden tegen, die hier te lande onbekend zijn, bv. de aftrekbaarheid in Engeland van ter bijpassing van een verlies in een gelieerde onderneming overgemaakte bedragen, de winstegalisatiemogelijkheden die de $Z$ witserse fiscus biedt en de regeling in Frankrijk voor de door inflatie veroorzaakte meerwaarden van vaste aktiva.

Het pragmatische karakter van genoemde maatregelen en rechterlijke uitspraken gekoppeld aan de omstandigheid dat deze hier en elders nog vrij algemeen als fiscale faciliteiten voor de ondernemers worden aangemerkt, bewijst dat herbezinning op het fiscale winstbegrip in de door Wisselink bedoelde zin dringend gewenst is te achten. 